\title{
Online Weld Quality Inspection System with Infrared Thermography
}

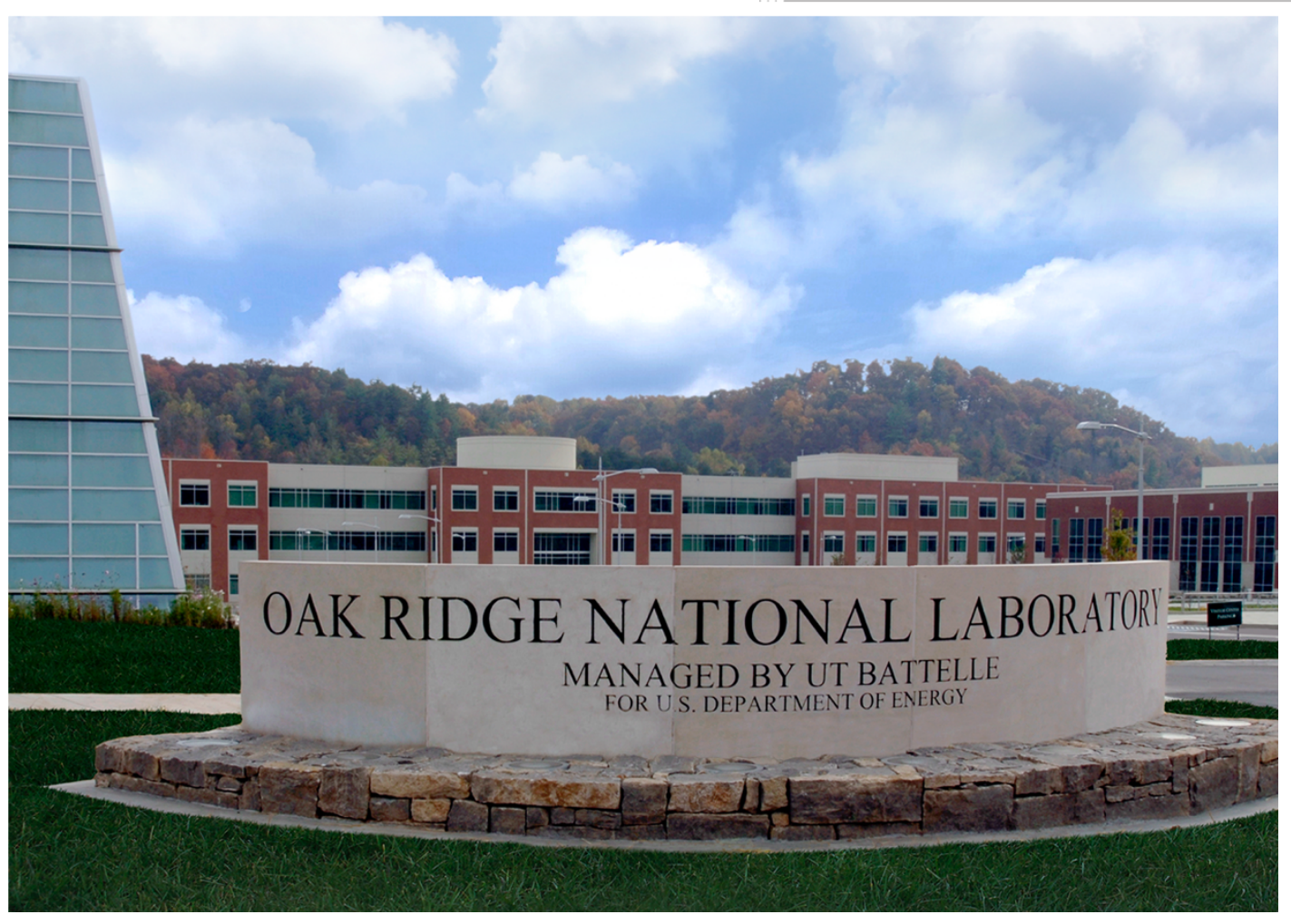

CRADA Final Report for
CRADA Number NFE-15-05619

Approved for public release. Distribution is unlimited.
Zhili Feng

Jian Chen

May 2017 


\section{DOCUMENT AVAILABILITY}

Reports produced after January 1, 1996, are generally available free via US Department of Energy (DOE) SciTech Connect.

Website http://www.osti.gov/scitech/

Reports produced before January 1, 1996, may be purchased by members of the public from the following source:

National Technical Information Service

5285 Port Royal Road

Springfield, VA 22161

Telephone 703-605-6000 (1-800-553-6847)

TDD 703-487-4639

Fax 703-605-6900

E-mail info@ntis.gov

Website http://www.ntis.gov/help/ordermethods.aspx

Reports are available to DOE employees, DOE contractors, Energy Technology Data Exchange representatives, and International Nuclear Information System representatives from the following source:

Office of Scientific and Technical Information

PO Box 62

Oak Ridge, TN 37831

Telephone 865-576-8401

Fax 865-576-5728

E-mail reports@osti.gov

Website http://www.osti.gov/contact.html

This report was prepared as an account of work sponsored by an agency of the United States Government. Neither the United States Government nor any agency thereof, nor any of their employees, makes any warranty, express or implied, or assumes any legal liability or responsibility for the accuracy, completeness, or usefulness of any information, apparatus, product, or process disclosed, or represents that its use would not infringe privately owned rights. Reference herein to any specific commercial product, process, or service by trade name, trademark, manufacturer, or otherwise, does not necessarily constitute or imply its endorsement, recommendation, or favoring by the United States Government or any agency thereof. The views and opinions of authors expressed herein do not necessarily state or reflect those of the United States Government or any agency thereof. 
ORNL/TM-2018/779

CRADA/NFE-15-05619

Technology Innovation Program (TIP)

\title{
Online Weld Quality Inspection System with Infrared Thermography
}

\author{
Zhili Feng \\ Jian Chen
}

Date Published: May 2017

\author{
Prepared by \\ OAK RIDGE NATIONAL LABORATORY \\ Oak Ridge, Tennessee 37831-6283 \\ managed by \\ UT-BATTELLE, LLC \\ for the \\ US DEPARTMENT OF ENERGY \\ under contract DE-AC05-00OR22725
}

Approved for public release. 



\section{Abstract}

Today's passenger vehicle on average contains 4,000 to 6,000 resistance spot welds (RSW). All US automakers perform destructive teardown evaluation to ensure the quality of the spot welds due to their criticality in crash resistance and performance of vehicles. The destructive teardown evaluation is labor intensive and costly. Sponsored by DOE VT Office, ORNL recently developed a prototype system (hardware and software) to non-destructively evaluate the quality of RSW based on infrared (IR) thermography. Highly cost competitive, ORNL's system has been tested extensively in the laboratory with initial successful production environment validation. Ford, Honda, GM, Chrysler and major Tier One suppliers all have shown keen interest in this new technology. ORNL's Technology Transfer Office licensed this technology to a small business (APLAIR Manufacturing Solutions) in TN. The licensee planned to develop a new hardware system based on ORNL's IR NDE technology for real-time online weld inspection. In this CRADA project, ORNL was tasked to assist the licensee to transfer the technology and develop the new product suitable for automotive body-in-white production environment, making the technology ready for 'real-world' auto-body assembly line production environment.

After the project initiated, the licensee recognized that the technical and industry expertise to carry out the technology maturation and commercialization is beyond their current capability. It decided to return the license to ORNL after several months. Most of the proposed tasks at ORNL in this project were not completed nor initiated. Over $70 \%$ of the funding was unspent and returned to ORNL system.

2. Statement of Objectives

The proposed work was built upon the ORNL's prototype system that had been tested extensively in the laboratory environment. In this CRADA project, ORNL planned to work with small business licensee, to transfer and further refine the ORNL's innovative IR NDE real-time spot-weld inspection technology. The project would convert the machine specific part (the front end) of ORNL's copyrighted IR NDE data collection and analysis source code so that it could be run and integrated with the new hardware platform planned for the licensee's products. The weld quality database (the back end of ORNL's copyrighted software) would be further tested and expanded to incorporate the new data set generated in this project. Finally, ORNL and the licensee would work together to build and test the real-time weld quality inspection system (hardware and software), in both laboratory and actual auto production environment.

The development, integration and testing of the new hardware would be conducted mainly by the licensee with ORNL's assistance. ORNL would also assist the licensee to convert the machine specific part of ORNL's copyrighted software source code to the new hardware platform. ORNL had previously developed a copyrighted and proprietary weld quality database that covers a wide range of advanced high-strength steels (dual phase, TRIP and boron steels). ORNL would continue to expand the weld quality database and make it compatible to the new hardware and software code.

\section{Benefits to the Funding DOE Office's Mission}

The new IR NDE technology has the potential to expedite the adoption of the advanced high-strength lightweight materials by automakers, resulting in the enhancement of the fuel efficiency and safety of the vehicles. This will strengthen the competitiveness of the U.S. automakers. Increased fuel efficiency also reduces the nation's oil consumption and greenhouse gas emission.

4. Technical Discussion of Work Performed by All Parties

The following are the completed tasks.

- ORNL helped the licensee identified a low-cost IR camera and tested it with the existing software in the laboratory.

- ORNL provided the source code to licensee and helped licensee to convert the code. 
5. Subject Inventions (As defined in the CRADA)

N/A

6. Commercialization Possibilities

Although the proposed work scope was not completed to the situation of the industry partner, ORNL keeps receiving interests and requests from other industry parties.

7. Plans for Future Collaboration

ORNL will keep working with industry parties to build more collaboration for eventual commercialization of the new technology.

8. Conclusions

The proposed work was to assist a small business technology licensee in TN to develop a new hardware system based on ORNL's IR NDE technology for real-time online weld inspection and the license agreement between ORNL and licensee. However, due to lack of technical experience, licensee decided to return the license to ORNL after several months. Most of the proposed tasks were not completed nor initiated. Over $70 \%$ of the funding was returned to ORNL system. 